\title{
The Yuridical Study of the Positive Law Challenges in Indonesia (Case of Phenomena Gratification on Trading Human Organ Body Crime)
}

\author{
Oksidelfa Yanto ${ }^{1}$, Susanto ${ }^{2}$, Muhamad Iqbal ${ }^{3}$, Yoyon Maulana Darusman ${ }^{4}$, \\ Guntarto Widodo ${ }^{5}$, Nani Widya Sari ${ }^{6}$ \\ Department of Law University of Pamulang South Tangerang, Indonesia \\ dosen00240@unpam.ac.id
}

\begin{abstract}
Any kind of trade in human body organs is a very criticized and prohibited under Law No. 36 of 2009 on Health. But in the case of success or failure of transplantation either by legal or illegal (human organ trade) requires the skills of a person who has expertise as a health worker considering the nature of organs when released from within the body is a sensitive item, in this case the quality these organs are donor-shaped conditions and the skills and abilities of medical personnel assisting in the transplant process. In the context of illegal activities in the process of transplantation of the organ of the trade result, the involved health personnel must be motivated by the lure of a large enough prize that is because of the illegal activities contain high risk both materially and the soul of the recipients and donors coupled with the value of the price of these organs is very high price. The use of the Criminal Code in the case of human body trade done by health personnel is a sure thing, but the trafficking of human organs must produce high gratification value enough to motivate the actors of health personnel to smooth the action of human organ trade. The research method used is normative juridical research, which is done by examining library materials or secondary data (library research). Where the stages of tracing and assessment of various sources with data collection, data assessment, interpretation, and conclusions are supported by field research, in order to obtain more accurate data about trading practices of human organs involving health personnel. Economic disparities and high levels of organ failure and human organ requirements result in bargaining prices of organs so high that the practice of organ trade will flourish. In organ trading activity is not an arbitrary case but there is a tendency of involvement of professionals who have knowledge and abilities in terms of transplantation of human organs.
\end{abstract}

Keywords: Criminal Law, Trafficking of Body Organs, Gratification of Health Workers

\section{Introduction}

Indonesia as a legal state based on Pancasila that protects all citizens of Indonesia and realize the welfare of all the people of Indonesia itself. As a state of law, it is appropriate that the law be supremacy in Indonesia, where all people in the territory of Indonesia are obliged to submit and obey without exception. It is very possible if there are enough legal tools to manage all sectors of life, in this case is the law that regulates the activities of the Health Manpower, therefore it is necessary to create a legal device that will determine the pattern of activity on the Health man 
power.

Indonesia is a developing country that is still affected by the economic disparity that plagues its people, it can be seen in some cases where people who voluntarily sell their organs to get money with a certain nominal. As happened in January 2016, the Indonesian public was thrown with the alleged trafficking practices of human organs in one of Indonesia's leading hospitals. It is certainly open the new assumption that in an effort to support the buying and selling activities of human organs, syndicates of human body trafficking has targeted medical professionals in this case unscrupulous Health Personnel as having the ability and authority in hospitals that have facilities in terms of organ transplants human body.

From the phenomenon, if we think it does make sense, considering in terms of taking human organs is not a matter of arbitrary but requires special knowledge (Specialist), considering it is very important in order to maintain the quality and value of selling the organ itself, therefore the mafia buying and selling of body organs will forge a mutual relationship with unscrupulous doctors who have knowledge of organs and have access to the transplant facility.

Previously it should be realized that technological developments, especially in the field of health, progress so rapidly in the search for treatment methods for several types of diseases. One of them is a new treatment effort that is organ transplantation, but technological progress in the health field is not balanced with progress in terms of the legal system especially the law specifically regulate the abuse of the ability of the Health Workers in this case surgeon and specialist Hospital health workers who are directly involved in the crime of human organ trafficking. A visible legal void over the regulations that oversee transplanting activities is often exploited by some unscrupulous individuals to seek personal gain. This is coupled with the facts in the field many people who are willing to sell their organs through prantara brokers (field actors in the syndicate organs of human organs or donors organs before) due to economic factors and the necessities of life. With the principle of profit-sharing, although it is not uncommon for the human organ-body brokers to be precisely in sharing the benefits of organ sales, the organ donor gets fewer dividends and certainly does not conform to the initial agreement or even in some cases the organ donor abandoned by the human body organ brokers without any division.

In 1950, the Indonesian Ulama Council (MUI) once announced a fatwa on the transplantation of human organs. In the fatwa was submitted that the transplantation of human organs is allowed, but that is not allowed or haram is buying and selling organs. Actually a person is not entitled to give his organs, the organ is not private property, and not purchased. Basically, a human being has been obeyed by the Creator to guard it. If there are people who need other people's organs, as long as it is not harmful, may be provided only not commercialized. Transplantation arrangements must be governed by the state so as not to be abused. The human organs selling often targeting poor areas because it is easily there the human body organs to fool the victims with certain of money. This kind of crime has evolved in the world from the first successful transplant of kidneys from donors to kidney donor patients in 1954 , the progress in the rapidly progressing transplantation field is in fact not matched by the ease of health services that can only be accessed by people at that time and things it happens to this day.

The journal Medical Update "Organ Transplant Tourism" on August 2007 said that it has become an international agreement that human organs are prohibited in the sale, although operating costs so expensive that not everyone can afford. The inability to provide stock organs will potentially lead to the sale of organs that are certainly illegal, in the sense that the poor sell 
their organs to the rich will continue.

Some online media contain lots of news about organ trafficking, but this is like a common sight. The problem that seemed to aggravate is that there is no single case of organ trafficking to date which is able to reach the level of the court even though there have been many unscrupulous individuals who did so openly until now the case of human organ trafficking involving three unscrupulous doctors in one famous hospital in Indonesia, news about it even now has begun to disappear closed other new issues. The anomaly seems to strengthen our logic that law or the ability of law enforcement officers have not been able to penetrate the dark side of the illegal practice of human organs trade especially in the world of health. Community mindset, especially in developing countries such as Indonesia is increasingly growing day by day due to the challenges faced by society today is increasingly complex, especially in matters relating to economy, in this case to get a bite of rice or other emergency needs, thinking to sell the organs they have as moving their organs to the needy people by getting a certain reward. But if it is related in private law in Indonesia that is in Article 1320 Civil Code then this kind of buying and selling is not in classification because the lawful so that null and void.

In the context of the phenomenon of gratuities in the business of organ procurement that led to the trade of human organs in the world of health is like an iceberg, the rampant cases seen in it there are indications of gratuities in the business of organ procurement that led to the human organs trade but which appear only on the surface a little. The number of cases of human organs trafficking that has led to the involvement of unscrupulous Health Personnel who act as a procurement broker of human organs make this issue should be discussed in the realm of law seriously, not just in the realm of ethics. A special legal rule with strict sanctions is necessary to prevent and combat the crime of organ trafficking because the principal actors involved in this crime are intelligent in terms of human anatomy. This is useful in providing legal protection and guaranteeing human rights especially regarding the right to life.

In Indonesia, organ harvesting from dead donors is not an easy matter. The organs should be taken when a person has experienced brainstem death, usually only occurring during the time interval of 5 (five) to 6 (six) minutes before the heart actually stops beating. If the process of organ harvesting or jantun already stops beating, then the organs can not be used again, although physically looks good condition, those aspects are convincing writers if crimes such as trading organs of the human body is a specialist crime, because in carrying out activities both legally and illegally still require the contribution of the hands of Health Workers who are experts in the field of anatomy and surgery to maintain the quality of these organs. The regulation of organ transplants in Indonesia is already stipulated in Law Number 36 Year 2009 on Health and Regulations on gratification in Article 12B in law Number 20 Year 2001 about corruption. The existence of regulations related to transplantation and gratification, whereas there has been no case of organ trafficking done by unscrupulous medical personnel to the court, is closely related to development and law enforcement.

The limitation of problem identifications are : What kind of Internal and External Factors causes the occurrence of crimes of human organs trading?; How Effective Enforcement Law Corruption in order to ensnare the perpetrators involved gratuities and mafia of organ trade in Indonesia? 


\section{Methodology}

This research uses normative juridical method. The normative juridical research method is also referred to as doctrinal research, which is a study that analyzes the law both written in the book, as well as the law decided by the judge through the law judge through judicial process.

\section{Results}

\section{1 Factors Causing Trafficking Human}

Criminal sanctions, especially in the case of human organ trade mafia capable of affecting preventively against perpetrators of crime and perpetrators of violations of human organs trade. The application of criminal law should only be applied if other efforts are not successful, and it is a tool of social control in society. Criminalization is a sanction contained in the criminal law which is also a distinctive characteristic that distinguishes the field of other laws. Currently medical science has grown rapidly, such as the existence of organ transplants. This medical breakthrough is done by replacing the patient's organs that are not working with the organs of other individuals, either from living or dead donors, allowed the Act. But behind the success, there are various problems. One of them is the practice of buying organs of human organs illegally.

In the case of legal sanction of a person who has the ability and access even accept the gift of something called gratification in this case the gift to use facilities and health capabilities that he has for evil such as participate in facilitating the trading of human organs, is not necessarily easy, it is because in the realm of criminal law in the context of gratification, a new person may be in law where the person is or the legal subject is a civil servant, a state organizer or a person receiving a salary from the state-sourced finance. As to where the essential point of Article 12B paragraph (1) that the Delik gratification is a offense containing about receiving a gift as a result of doing or not doing something in his position.

The interpretation that the trafficking of human organs as malpractice is somewhat mistaken given that the formal law of crime is clearly a special criminal act in Indonesian law and is materially legal is not justified because it is considered blameworthy and can have implications for other criminal acts to obtain organs In its development, the unlawful nature of the law in criminal law is distinguished by negative functions and positive functions. Loebby Luqman outlines the negative meaning of the unlawful act of materially stating that "the act of unlawfully materially must be used negatively, this means that if there is a real act it is unlawfully formally, whereas in the society the act is not reprehensible, so materially not against the law, the act should not be criminalized ". While in this context the act of trading in the organs of both private property and others is a very reprehensible thing.

In many ways, there is no justification that the sale of human organs is justified by law. For that, there is no other way law enforcement should be able to solve this problem up to the upstream. The syndicates, ranging from sellers, intermediaries, to doctors who terlinat should be dealt with firmly. This state law umbrella is ready to ensnare anyone involved in it. Both medical experts and sellers and recipients. They will be faced with Law on Health "It is not justified that a 
doctor performs a transplant operation using an illicit sale organs". Article 64 paragraph (2) states that the organ transplant and / or body tissue conducted only for humanitarian purposes and forbidden to be commercialized, "The violation of the article shall be punishable by imprisonment. Article 192 provides that anyone who intentionally sells the organ is punished with imprisonment for a maximum of 10 (ten) years.

\subsection{External Factors That Cause The Rise Of Illegal Business Trafficking Of The Human Body Organs}

\section{a) Health Factors}

Complete and healthy body organ is everyone's dream, the condition can also support happiness in a human life. But if there is one organ that suffered damage of course, the human must make medical efforts from taking medicine until the last step of the transplantation of their body tissue, either Autograft, Allowgraft, Isograft, Xenograft to return to healthy conditions as before. However, in the case of transplant constraints in Indonesia is still very high, not only from the cost of such transplants are expensive but also to get someone who sincerely and voluntarily give his organs are to be transplanted still somewhat difficult even rare. If the donor is willing to give his organs sincerely for transplantation, the recipient is still not calm in because whether there will be a rejection reaction from the recipient's body that can happen immediately on the table operation after a few days or weeks. Apart from that as an effort to prevent from the state of organ failure, should people in this modern era maintain good health of their organs by applying a healthy lifestyle such as exercise routine, healthy foods, lean and include balanced nutrition intake. And in that case should always check the health routinely in an effort to prevent organ failure.

\section{b) Economic Factors}

Sales of organs are very likely. But if done in ways that evil certainly not allowed. Something similar has happened in Singapore involving Indonesian citizens, where two Indonesian citizens were arrested in Singapore for selling their organs. although there is no official data on how many Indonesians have sold their men, but with the two men in Singapore it is evident that it is real. Donors who are destitute and relatively uninformed receive only US \$ 1000 maximum US \$5000, but because of the poor conditions they accept only the amount of money given. Compare this with the amount of money the broker receives at US \$100,000 and US \$200,000 which only organizes transplants for the rich. The reasons for poverty and coupled with a corrupt government will greatly encourage tremendous organ trafficking. although it has been regulated in the laws of India. that the kidneys can only be donated from the blood family, husband / wife, but the rules are bent only for the sake of someone. The polemic regarding the high cost of transplantation, making this treatment technique very difficult to be done by people with mediocre economy, such as the case of experienced Bilqis where to get treatment handling using Bilqis transplantation technique requires a cost between $\mathrm{Rp} 800$ million to 1 billion rupiah. As for the preparation of kidney transplants in the hospital in the country ranges from Rp 28.5 to Rp 35 million. until a patient who wants to transplant in Indonesia at least have to bribe money $R p 80$ to $R p 250$ million.

Unfulfilled between the demand and availability of human organs, a clear constraint occurs in 
the treatment effort by means of transplantation, the more unbalanced between availability and demand encourages people to justify immediate efforts amid the urgency of the needs of organs in order to treat the failure of organs they have, including to get it someone willing to buy it from the black market.

\section{c) Social Factors}

According to Indrawati, in addition to the actual dialysis of kidney transplant or transplantation is the best way to overcome terminal kidney failure disease. But still the way there are obstacles because not many parties are willing to be a donor. Most of the transplants that occur in Indonesia from living donors generally come from their own families, relatives or friends. Lack of kidney donors because of the concerns of life with just one kidney. Though it is medically healthy human can live normal with one kidney. It seems that this kind of knowledge has not yet spread to the community so an effective socialization program is needed. The difficulty of finding people willing to voluntarily donate their organs, causing the appearance of suspicion in various circles of human organ transplant process in the color aka buying and selling, the existence of compensation that is not transactional. And it is obviously banned in Indonesia. In addition to explaining not entitled to compensation for the donor who donated his organs, in Law No. 36 of 2009 on. Therefore, in need of a very hard rule in an effort to close the business opportunities illegal trading of human organs in the midst of the condition of the people of Indonesia are full of preamble. So a very strict and loud provision will probably be apertured.

The question is whether or not the perpetrators of the sale and purchase of organs will still be considered in violation of the law if they claim compensation as a thank-you and it is not binding. Or the provision of organs for the transplant on the basis of a familial relationship that is compensated. This creates new loopholes for law enforcement in the fight against human organ trafficking. Knowledge of the laws governing the practice of transplantation is indeed in need. The procedure of the relationship between the donor and the recipient who is a party to each other is born because the voluntary principle known by his family and / or heirs resulted in no legal impact occurred.

\section{d) Internal Factors That Cause The Rise Of Illegal Business Trade in Human Body Organs}

The demand for increased organs will surely boost the selling price and services of organ transplants, as previously described unequal or irrational remuneration will tend to make potentially tempting health workers tempted and tempted by the offer of their services and facilities that are illegally authorized in this case participate in smooth the occurrence of trading practices of human organs. This review of the issue is crucial because basically. Starting point entire planning of the functional process of criminal or criminal law or process is the stage of formulation that forms the basis, application stage and stage of execution. This review of the issue is crucial because basically starting point of the entire planning of the functional process of criminal or criminal law or process is the stage of formulation that forms the basis, application stage and stage of execution.

In the context of trade in human organs in Law No. 36 Year 2009 on Health does not specifically regulate and separate the classification and quality of abilities of actors involved in 
human organs trading either from civil or health workers (Private and Civil Servants), it also contributes to nowadays that currently no single case of human organ trafficking in Indonesia that reaches the court.

Leadership of law enforcement officers is determined by the attitude of leaders who are consistent, committed, and always have the competence in handling and overcoming criminal acts. In addition to professional skills, no less important is the form (performance) of law enforcement officers are clean and authoritative in order not to abuse the authority. In the case of human body organ trafficking, law enforcement officers are still preoccupied with very difficult proofs. This is related to the quality of the crime that is in desperate need of interpretation in the field of health.

\section{e) The Effectiveness of the Implementation of Criminal Sanctions}

The term criminal offense in Dutch is strafbaar feit which is actually an official term in Strafwetboek or the Criminal Code (Penal Code) currently in force in Indonesia, the term in foreign language is delict. Crime means an act whose perpetrator can be punished. In the view of the Criminal Code which is the subject of criminal offense is human being as an individual. The objective element is when the element is outside the creator (buiten de dader aanwezing) which can be: First, an act is "something something" and can be "do nothing". Second, it is a consequence. Third, problem-solving, circumstances which are all prohibited and threatened by penalties by the Law.

Corruption in Indonesia has been in severe condition, almost all the joints of human life have been infected with this disease, including in the field of health and in professional professions belonging to health workers. Marzuki Darusman stated, The spread of Corruption, Collusion and Nepotism was so widespread that radical radicals could be said. Recently, Indonesia was thrown at the alleged trafficking of human organs that occurred in one of the big hospitals in Bandung, which clarified a fact that human trafficking syndicates have targeted and co-operated professionally owned professions, facilities and facilities for transplant needs.

In the Elucidation of Article 12B Paragraph (1) of Law Number 20 Year 2001 referred to as gratification is a grant in the broad sense, which includes the provision of money, goods, rebates, interest-free loans, travel tickets, lodging facilities, travel, -free and other facilities. Such gratuities are accepted both domestically and abroad and are carried out by means of electronic means and without means of electronics. Thus, if we look more broadly, then gratification can be good and bad. Gratification is good if the gift is given sincerely sincere, does not have a particular purpose and purpose associated with the position is bad if the gift is aimed at pamrih, affecting the decisions of someone related to the position or profession.

The cause of gratification which is one of the criminal acts of corruption in the health professional profession until it ends in abusing medical ability to transmit human organ trade activity, in this case Jack Bologona introduces GONE (Greed, Opportunity, Need, Exposes) Theory, as the following: Greed, Corruptor is a person who is not satisfied with his condition. Despite having a mountain of gold, but still not satisfied desire to master the other gold mountains. Got a myriad treasure, igin pulai private. This is related to the attitudes and behavior of health personnel themselves, some feel quite and grateful with what they already have and there are also always feel less satisfied with what already exists. Meanwhile, Opportunity, namely the existence of a system that can then give a gap to the occurrence of criminal acts of corruption. There is a 
chance between Mafia Trafficking Organ that does not have medical ability, buyer of human organs and health personnel to do collusive mutual with Gratification to benefit the three parties but harms the donor because there is procedural pass or jump. The monitoring system on coalism is not strict and the difficulty in terms of proof of it also shows the fact that to date the crime of human organ trade has not reached the court level. It also relates to the authority given to health workers in the treatment of patients.

Need, in the profession of health workers in relation to income disparity between salaries of health workers with civil servant (civil servants) bersetatus not in accordance with the duties and responsibilities are such that as a major change in the field of health and healers. As it is known that the salaries of doctors Civil Servants only ranged between 2-3 million rupiah per month. Salary is very inhumane, not enough to meet the needs of his life because doctors work from morning to evening. For doctors who work in many areas who have no other income than salary. Then Exposes, related to the low legal supermarkets in this country that makes not the players of the perpetrators of corruption. It is a very potential to make the activity of human organ trafficking can occur and done by unscrupulous health personnel, especially in the ability, knowledge and facilities they are quite mastered and have it.

Gratification in Article 12 B Paragraph (2) of Law Number 20 Year 2001 concerning the Eradication of Corruption, so that this offense comes in that the subject of delik is divided into two groups, both if the criminal act is threatened with sanctions. Criminal sanctions are granted, subject to applicable law of corruption. Both subjects or perpetrators of the offense are: i) civil servants (Civil Servants) ii) State Organizer. Basic Act of Personnel Number 18 Year 1961. This law has been revoked and replaced by Law Number 8 Year 1974 which was later amended by Law Number 43 Year 1999 regarding the Amendment of Law Number 8 Year 1974 on the Principles Civil Service Personnel. Article 1 section 1 of Law Number 43 Year 1999 reads: "The civil servant is any citizen of the Republic of Indonesia who has met the prescribed requirements, appointed by the competent authority and assigned the duty in a state office, or assigned to another State, applicable laws and regulations ". Article 2 Paragraph (1) of the Criminal Code distinguishes civil servants over three groups: 1) Civil servants. 2) Members of the Indonesian National Army. 3) Article 2 paragraph (2) states that public servants consist of: Central civil servants. Regional civil area. 4) Article 2 paragraph (3) declare disampaing civil servants as referred to authorized officials may appoint permanent employees.

From the above, it is very clear that the use of Article 12 B of Law Number 20 Year 2001 concerning the Eradication of Corruption Crime can be used if the subject of the gratification actors is in accordance with the regulation namely Civil Servant (PNS) and or the State Organizer. In the case of Gratification in order to facilitate the operation of human organ trafficking and illegal transplantation, the absolute requirement in accountability of gratification perpetrators in Law Number 20 Year 2001 concerning the Eradication of Corruption Crime shall be the perpetrator must be a civil servant and civil servant. Because if the requirement is not met then the actor who receives the gratuities to launch the organ trading activity and the illegal transplant is only responsible and subject to the Law Sanction Law Number 36 Year 2009 Regulation on Health, which deals with the trading of human organs and illegal transplantation. 


\section{Conclusions}

Supporting factors that cause the trafficking of human organs in Indonesia proceeds with the high demand for donation and transplantation for the benefit of medicine and health caused by the organ that is damaged, of course in overcoming the health problem must make medical effort from taking medicine until the last step that is transplantation tool or tissue of their body, either by Autograft, Allowgraft, Isograft, Xenograft to return to healthy condition as before. But in the case of transplant constraints in Indonesia is still very high, not only from the cost of transplant but rather unbalanced between the demand for organs in the transplant with the scarcity of human organ stocks. The waiting period is not too long to make the business and trading activities of human organs continue to flourish in high conditions, the price of human organ procurement illegally is not cheap. The effectiveness of criminal sanctions in Article 12B paragraph (1) and (2) of Law Number 20 Year 2001 concerning the Eradication of Corruption and the Law Number 36 Year 2009 on Health in law enforcement efforts against perpetrators who have quality and position with the subject of Gratification as stipulated in Law Number 20 Year 2001 on the Eradication of Corruption can be carried out but it is only bumped into the evidence in the context of the crime of organ trafficking as an early crime, the obstacle faced in this case is Legality (Law / Regulations) that have not firmly separate the subject of common law and specialist profession professions, Events in Courts, Written Defense by lawyers and Witnesses until Evidence is hard to obtain to prove the occurrence of crimes of human organ trade ending with gratification.

\section{Suggestions}

Socialization of the community about the importance of donating organs to the purpose of humanity to others who suffer from organ failure and there is no other option for him in addition to organ transplantation and openness IDI (Indonesian Doctors Association) in terms of control of human organs trade, for the law positively capable of securing the profession from potential lawlessness in the case of human organ trafficking conducted by internal physicians and the public can see, assess to observe that IDI is completely free from the trafficking of human trafficking mafia cartels, and to prevent and combat trafficking crimes the human organs of the human body are either organized in a chapter separately divided by two subjects in it either between the actor possessing the knowledge and skill (propria) with the heaviest punishment and the ordinary people (comuna) in order to make the penal law applicable by effect tif. Because in the case of human organ trafficking this Propria actor is more aware about the impact of risk than the perpetrators of Comuna that make the subject tends to potentially be being used at the pretext of the economy.

\section{Acknowledgements}

The authors would like to express gratitude to Research and Development Centre University of 
Pamulang for supporting and financing this research. Thank you to Amir and Budi for their help during the study.

\section{References}

[1] Abraham Hayward, of The Vocation of Our Age For Legislation and Jurisprudence (Translated Form The German Of Frederick Charles Von savigny), USA: Bodleian Library Oxford, 1831.

[2] Andi Hamzah, Asas-asas Hukum Pidana, Rineka Cipta, Jakarta, 2008.

[3] A.Z. Abidin, Andi Hamzah, Hukum Acara Pidana di Indonesia, Sumur Bandung, Bandung, 1962.

[4] Adnan B.N, Pergulatan Tanpa Henti, Pahit Getir Merintis Demokrasi, Aksara Karunia, Jakarta, 2004.

[5] Barda N.A, Kebijakan Legislatif dalam Penanggulangan Kejahatan dengan Pidana Penjara, Semarang, Badan Penerbit Undip, 2000.

[6] Black, Henry Campbel, MA, Black's Law Dictionary, Definition Of Term And Fhrases Of an American and Englich Yurisprudence, Ancient and Modern, 4th Ed West Publising and co, 1968.

[7] Chazawi Adami, Hukum Pidana Korupsi di Indonesia, Rajawali Pers, Jakarta, 2016.C.S.T. Kansil \& Christine S.T. Kansil, Pokok-Pokok Hukum Pidana, Hukum Pidana Untuk Tiap Orang, Pradnya Paramita, Jakarta, 2004.

[8] Fuady, Munir., Sumpah Hippocrates (Aspek Hukum Malpraktek Dokter), Citra Aditya Bakti, Bandung, 2005.

[9] Trini Handayani, Fungsionalisasi Hukum Pidana Terhadap Perdagangan Organ Tubuh Manusia, Mandar Maju, Bandung, 2012.

[10] Krisna Harahap, Pemberantasan Korupsi Jalan Tiada Ujung, PT Grafiti, Bandung, 2006. Hendrojono H. Soewono., Batas pertanggungjawaban Hukum Malpraktik Dokter Dalam Transaksi Terapeutik, Srikandi, Surabaya, 2005.

[11] Loebby Loqman, Percobaan Penyertaandan Gabungan Tindak Pidana, Universitas Tarumanegara UPT, jakarta, 1995.

[12] Moeljatno, Asas- Asas Hukum Pidana, Bina Aksara, Bandung, 1987.

[13] Muhammad Mustofa ; Kriminologi : Kajian Sosiologi trhadap Kriminalitas, Pelaku Menyimpang dan Pelanggaran Hukum. Jakarta. Fisip Ui Press, 2007.

[14] Mochtar Lubis \& James C. Scott, Bunga Rampai Korupsi, LP3ES, Jakarta, 1995,

[15] M. Solly Lubis, Pembahasan UUD 45, Bandung, Alumni, 1985. Muladi, Lembaga Pidana Bersyarat, Alumni, Bandung, 2002.

[16] Barda Nawawi Arief, Teori-teori dan Kebijakan Pidana, Alumni, Jakarta, 1998.

[17] Munir fuady, Teori Negara Dalam Hukum ModernI (Rechtaat), Bandung, Refika Aditama, 2009.

[18] Marella B, dalam Hans Otto Sano, et.al., Hak Asasi Manusia dan Good Governance, Membangun Suatu Ketertiban,(alih bahasa oleh Rini Adriati), DepKumHam, Jakarta, 2003.

[19] Peter Salim, Kamus Bahasa Indonesia Kontemporer, Modern English Press, Jakarta, 1991.

[20] P.A.F lamintan g, Delik-Delik Khusus, Kejahatan Terahadap Nyawa Tubuh Dan Kesehatan Serta Kejahatan Yang Membahayakan Bagi Nyawa, Tubuh Dan Kesehatan, Bandung, Bina cipta, 1968.

[21] S.H Syed Hussein Alatas, Coruption:its Nature, Causes and Consequences, Aldershot and Brookfieeld, Vt.Evebury, 1990.

[22] Siswanto Sunarso, Wawasan Penegakan Hukum di Indonesia, PT Citra Aditya Bakti, Bandung, 2005.

[23] Soesilo dan Pramudji, Kitab Undang-Undang Hukum Perdata, Wipress, Jakarta. 2007. Van Houve, 
Ensiklopedi Indonesia, PT. Ichtiar Baru, Jakarta, 1986.

[25] Wirjono P, Tindak-Tindak Pidana Tertentu di Indonesia, Refika Aditama, Bandung, 2008.

[26] Wiyono R, Pembahasan Undang-Undang Pemberantasan Tindak Pidana Korupsi, Sinar Grafika, Jakarta, 2005.

[27] Nyoman Suwasti, Aspek Yuridis Transplantasi Organ Dalam Hubungannya dengan UU Kesehatan, Kertha Patrika, Majalah Ilmiah Fakultas Hukum UNUD, Bali, 1994.

[28] Fatwa MUI tentang transplantasi organ tubuh, diunduh di Internet tanggal 26 Februari 2016. Edi, Di Malaysia Otopsi Tak Wajar Organ Tubuh Tiga TKI Hilang, Kedaulatan Rakyat, 2012. 